\title{
Podcast Media in Consultation Services to Develop Academic Stress Prevention Skills
}

\author{
Purwadi $^{1}$, Irvan Budhi Handaka ${ }^{2}$, Suharsimi Arikunto ${ }^{3}$, Hardi Prasetiawan ${ }^{4}$, Nurlita \\ Hendiani $^{5}$, Rahmat Ponco Adi Saputra ${ }^{6}$ \\ 1,2,3,4,6 Universitas Ahmad Dahlan, Indonesia \\ ${ }^{5}$ National Narcotics Agency \\ Email Address: hardi.prasetiawan@bk.uad.ac.id
}

Submitted : 10-09-2021, Revised : 23-10-2021, Accepted : 24-11-2021

\begin{abstract}
The rapid digitization of education in a pandemic has an impact on academic stress conditions. Counsellors have not implemented various innovative media but need relevant and millennial media to support consulting services with podcasts. This article aims to analyze the feasibility of podcast media in consulting services to develop academic stress prevention skills. Research and development limited to five stages help know the feasibility of podcasts as support for consulting services, especially academic stress prevention skills. The data analyzed the feasibility questionnaire instrument through expert validators, media, and practitioners (counsellors) quantitatively with percentages and inter-rater analysis. The results of the research show that podcast media is quite relevant to use in consulting services. The relevance and accuracy of podcast media can adjust to the content of the supporting material. Prevention of academic stress isn't only with knowledge but skills to cope with academic stress in all conditions, especially in pandemic and post-pandemic situations. Professional and millennial counsellors can develop skills in the use of podcast media in consulting services. Can use Podcast media directly in consulting services. Recordings of podcast results can be used indirectly in consulting services or group guidance services, group counselling, individual counselling, and classical guidance as a follow-up.
\end{abstract}

Keywords: Academic stress; Consultation; Podcast media

\section{Introduction}

Assistance to students as part of sustainable self-development is an element of education (Suriansyah, 2011). The pandemic era since 2020 has opened the gates of digital education, which limits academic actualization (W. N. E. Saputra, Wahyudi, et al., 2021). However, many lives in Italy, Iran, South Korea, England, China, Japan, the United States, Germany, and other countries, including Indonesia (Aminah, 2020) have been affected big. A school is a place for the learning and self-development of students, one of which is the ability to manage educational problems, personal planning, social planning, academic planning, and career planning. The basic concept is that student's success and failure levels are created under current conditions (Sibuea \& Safta, 2017). Student achievement is past the minimum assessment criteria (Yuneti, 2017). Achievement is a new spirit and fighting power because it has a significant impact on self-confidence.

Various obstacles in online learning and blended learning arise. The ability to adjust learning from face to face, then online and changing to blended learning as a change in learning models (Minister of Education, 2020). The demands of the implementation of learning cause academic stress on students and require solutions for teachers, students, and parents. Parents and friends as supporting factors for preventing academic stress (Mosanya, 2021). Academic stress will harm cognitive function and memory function in an individual's brain (Lin et al., 2020). 
The fact that academic stress conditions impact academic performance is the cause of severe academic stress (Mahapatra \& Sharma, 2020). Another point is that academic stress significantly affects students' fear of the future (Moawad, 2020). The condition of academic stress that occurs due to the Covid-19 pandemic has a significant effect on the learning system and student conditions. Stress is a psychological pressure to overcome obstacles and limitations in the process of life (Muslim, 2020). Stress is a form of experience based on self-view in reality conditions (Gunarya etc., 2010). Stress is closely related to self-pressure in needs of reality and the emergence of anger, feelings of disappointment, and anxiety about the emergence of failure.

Students in a pandemic or post-pandemic conditions still arise problems related to online and blended learning assignments, resulting in academic stress. Personal pressure impacts learning as part of academic stress (Barseli etc., 2017). Academic stress conditions affect the learning process and achievement and health and sleep disorders (Oktavia etc., 2019). School counsellors play a significant role in student education and students' ability to manage student problems, especially academic stress. School counsellors play a significant role in student education and students' ability to manage student problems, especially academic stress. Assistance from school counsellors plays a role in preventing academic stress through psychosocial interaction interventions and stress coping (Joseph et al., 2021; Sari et al., 2020; Shehadeh et al., 2020).

The role of guidance and counselling in consulting services is to help develop skills in managing academic stress. Consulting services as an intervention strategy help reduce problems individually or in groups (Suryani, 2017). Consulting services assist individuals in problem-solving rather than process-oriented knowledge and skills (Fan et al., 2021). Process orientation in consulting services is exciting in developing students' self and skills towards preventing academic stress. The use of media as an attraction to generate enthusiasm and enthusiasm in consulting services. As an alternative in channelling messages, media can stimulate thoughts, feelings, and wills (Ekayani, 2017). Podcasts as one of the relevant media supporting consulting services in the digital and millennial era. Online counselling is a strategy to prevent academic stress (Janna, 2021) ; a consultation can reduce academic stress (Dewi \& Muslikah, 2021).

Podcasts as relevant and millennial media to use in consulting services. The use of podcasts as an alternative media with sound or audio is preferred by millennial or postmillennial individuals (Saputra \& Muharammah, 2020). Podcast media is a new form of innovation to develop students' academic stress prevention skills in consulting services by counsellors. Podcasts as a digital medium with a series of audio or video episodes (Kusuma et al., 2020) is innovative and creative for counsellors. This research aims to emerge the feasibility of podcast media in consulting services to develop students' academic stress prevention abilities.

\section{Methods}

This study has three variables. The variables are (a) academic stress of students in online and blended learning conditions, (b) consulting services by counsellors, and (c) podcast media as a support for consulting services. The three variables are adjusted to current conditions and millennial and digital guidance and counselling services. The research and development design concept is limited to the fifth stage. The podcast media development stage in consulting services for academic stress prevention skills is based on the preliminary study in the first stage. The second stage is to prepare a hypothetical draft of academic stress prevention materials and consulting services with podcast media. The third stage is developing 
podcast media that can be implemented in consulting services with academic stress prevention skills. The service study is the fourth stage for validators of material experts, media experts, and practitioners, namely counsellors. The fifth stage is the revision of the service study, which has been analyzed qualitatively and quantitatively.

Eligibility questionnaires to validators according to material experts, media experts, and practitioners, namely counsellors, to determine the feasibility of podcast media. The results of the service study as the final design of podcast media for the development of academic skills to prevent student stress in a pandemic or post-pandemic conditions by counsellors. The last data is discussed qualitatively. Quantitative analysis as an element of the feasibility of podcast media in consulting services. The first stage is the results of the feasibility analysis from material experts, media experts, and practitioners (advisors) quantitatively with percentages. The second stage is internet analysis with the help of the SPSS application to determine the reliability of podcast media. The results of the interpretation of the feasibility of media experts, material experts, and practitioners, with the support of trusted media podcats in counselling services as the final data.

\section{Results and Discussion}

Media podcasts from the feasibility test results get assessments from material experts, media experts, and counsellor practitioners. The media expert's evaluation results in media expert's evaluation with an average value of $90 \%$ can be used for the development of academic stress prevention skills. Media experts rate with an average score of $85 \%$, so podcasts as a media consulting service help students with academic stress prevention with various skills. Counsellors in schools assess podcasts as media for the current era with an average score of $90 \%$. The average rating of the three assessments is $88.3 \%$ or excellent criteria. The evaluation results recommend that the podcast media support consulting services by counsellors, especially the prevention of academic stress. The feasibility of Podcast Media in Consulting Services for Academic Stress Prevention Skills Development can be seen in table 1.

Table 1. The feasibility of Podcast Media

\begin{tabular}{ccc}
\hline No & Product Test Aspect & Average Value \\
\hline $\mathbf{1}$ & Material Expert Test & $90 \%$ \\
\hline $\mathbf{2}$ & Media Expert Test & $85 \%$ \\
\hline $\mathbf{3}$ & Test of Practitioner or Counselor & $90 \%$ \\
\hline & Amount & $265 \%$ \\
\hline & Score & $88,3 \%$ \\
\hline & Category & Very good \\
\hline
\end{tabular}

Table 1. shows the average value of several aspects, namely from the $90 \%$ Material Expert Test, 85\% Media Expert Test, 90\% Practitioner or Counselor Test. In very good category. Furthermore, the Podcast Media-Interrater reliability test in consulting services for academic stress prevention skills development can be seen in table 2 . 
Table 2. Podcast Media-Interater Reliability Test

\begin{tabular}{lrrrrrrr}
\hline & \multirow{2}{*}{$\begin{array}{c}\text { Intraclass } \\
\text { Correlation }\end{array}$} & \multicolumn{3}{c}{ 95\% Confidence Interval } & \multicolumn{3}{c}{ F Test with True Value 0 } \\
\cline { 3 - 8 } & & Lower Bound & $\begin{array}{c}\text { Upper } \\
\text { Bound }\end{array}$ & Value & df1 & df2 & Sig \\
\hline Single Measures & $.500^{\mathrm{b}}$ & .109 & .821 & 4.000 & 9 & 18 & .006 \\
\hline $\begin{array}{l}\text { Average } \\
\text { Measures }\end{array}$ & $.750^{\mathrm{c}}$ & .268 & .932 & 4.000 & 9 & 18 & .006 \\
\hline
\end{tabular}

In table 2, Tested the results of the assessment for reliability with the Intraclass Correlation Coefficient (ICC). The results of the Intraclass Correlation Coefficient test with a significance of $0.006 \leq 0.05$. These data indicate that podcast media in consulting services are relevant and feasible in developing academic stress prevention skills. The analysis for the consistency rater is 0.750 , which means it has a pretty good consistency. The meaning of good enough is that podcast media in consulting services is quite relevant to developing students' academic stress prevention skills.

Podcasts as a communication medium communicate with other people and convey information (Sudarmoyo, 2020), in contrast to YouTube media used to increase enthusiasm (Jannah \& Baqiyatussolihat, 2021) share information. Podcast media is relevant compared to other media because it can be used directly or indirectly as a messenger. Podcast media can publish through youtube media which can also increase student enthusiasm. This media is applicable as a consultation media in developing academic stress prevention skills.

Podcasts as audio-visual media as messengers through the internet network with millennial devices (Rajic, 2013). Can indirectly podcast media in consulting services through iPhones, cellular phones, laptops, and other computer devices. The podcast themes are varied and creative to support the professional counsellor profession in any field, making it relevant for post-millennial era counsellors. Can also upload the results of podcast media recordings via YouTube and Instagram. Podcast media has the advantage that it can be uploaded and reused in guidance and counselling services, as well as learning media (Dewanti \& Sujarwo, 2021), especially in preventing academic stress.

School counsellors' podcasts in consultation services can convey messages and various content through broadcasts or face-to-face (Ridha, 2021). Can also use Instagram media in consulting services to prevent academic stress, although with exciting content. Instagram is useful as a form of knowledge exchange and affective support (Carpenter et al., 2020) but has a long-term impact on Instagram addiction (Ponnusamy et al., 2020). Meanwhile, podcast media in preventing academic stress are also a face-to-face exchange of knowledge and affective support, moral messages, tolerance attitude (Supriyanto et al., 2019).

Podcasts are indirectly in audio and video that others can listen to (Laila, 2021). Postcast variations and innovations in consulting services are relevant and meaningful to students or counselees. Individuals with academic stress problems can listen and analyze the content of messages directly from the podcast media. If they meet face-to-face with a counsellor, they can practice skills in preventing academic stress. As shown in Figure 1, podcasts are interactive media that support professional counsellor consulting services for academic stress prevention. Podcasts can disseminate specific information(Quintana \& Heathers, 2021), preventing academic stress with access to educational and social news (Casares Jr \& Binkley, 2021). 


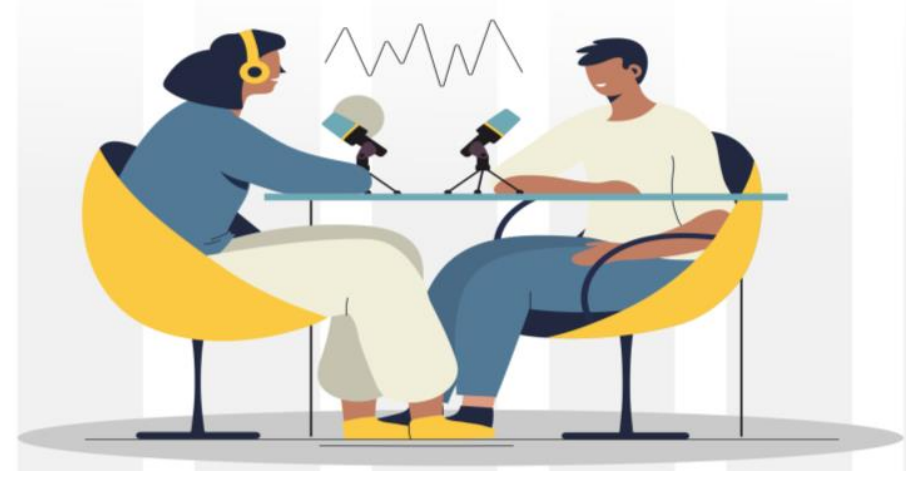

Figure 1. Interactive Media Podcast

Podcasts from research results combined in consulting services to develop academic stress prevention skills according to the steps for making podcasts. Podcasts are generally made from pre-production, production, and review (Mayangsari \& Tiara, 2019). The three stages of consulting with podcast media to develop academic stress prevention skills have fulfilled the pre-production stage with needs analysis and relevant content in academic stress prevention with skills for students. Production is carried out directly in the implementation of consulting services, and then it can be helpful for students as video and audio media. The review of podcast results can be used as a follow-up for classical guidance services, group guidance, and counselling services. Message content, material content, the follow-up to podcasts (Chan etc., 2006) are relevant for counsellors to use.

The podcast media is a learning tool with interesting, exciting material (Fadilah etc., 2017). Podcasts also provide convenience for learning purposes (Asmi, 2019). Especially in consulting services, podcast media can be used anytime and anywhere by re-listening or downloading through the WhatsApp Group application and the web (Abidin \& Widodo, 2018). Counsellors must be able to create innovations in consulting services. Innovations in consulting services with various conditions of changing the digital education system must create a school climate. Counsellors must be able to create a positive school climate that impacts the development of academic achievement (W. N. E. Saputra, Supriyanto, et al., 2021). Various innovations with podcast media by counsellors can help individuals to be able to prevent their academic stress.

\section{Conclusions and Suggestions}

Academic stress due to the Covid-19 pandemic has an impact on the world of education. Academic stress affects learning achievement. Professional counsellors use face-to-face or virtual consultation services with podcast media. Media podcasts are relevant and appropriate to use to help prevent academic stress. Material content in academic stress prevention is supported and integrated to foster skills in helping academic stress prevention. Podcast media can be implemented directly in consulting services or indirectly so that podcast media recordings can be downloaded or viewed again as a support for guidance and counselling services.

The urgency of the future counsellor's professionalism with the use of digital media is by podcasts in guidance and counselling services. Relevant podcasts in the implementation of guidance and counselling services, primarily consulting services. Consultation with individual 
settings or group settings with podcast media is an element of novelty in the millennial era. Professional counsellors continuously adapt to the development of the digital age in guidance and counselling services.

\section{References}

Abidin, J. D., \& Widodo, S. (2018). PENGEMBANGAN MEDIA AUDIO BERBASIS PODCAST MATERI STORY TELLING MATA PELAJARAN BAHASA INGGRIS KELAS X JURUSAN REKAYASA PERANGKAT LUNAK SMK KRIAN 1 SIDOARJO. Jurnal Mahasiswa Teknologi Pendidikan, 9(2).

Aminah, S. (2020). Good looking; bullying and insecure.

Asmi, A. R. (2019). Pengembangan Media Pembelajaran Audio berbasis Podcast pada Materi Sejarah Lokal di Sumatera Selatan. Historia: Jurnal Pendidik Dan Peneliti Sejarah, $3(1), 49-56$.

Barseli, M., Ifdil, I., \& Nikmarijal, N. (2017). Konsep stres akademik siswa. Jurnal Konseling Dan Pendidikan, 5(3), 143-148.

Carpenter, J. P., Morrison, S. A., Craft, M., \& Lee, M. (2020). How and why are educators using Instagram? Teaching and Teacher Education, 96, 103149.

Casares Jr, D. R., \& Binkley, E. E. (2021). Podcasts as an Evolution of Bibliotherapy. Journal of Mental Health Counseling, 43(1), 19-39.

Chan, A., Lee, M. J., \& McLoughlin, C. (2006). Everyone's learning with podcasting: A Charles Sturt University experience. Who's Learning, 111-121.

Dewanti, S. R., \& Sujarwo, S. (2021). Development of Instagram and YouTube Content Videos' for Online Learning. Jurnal Penelitian Ilmu Pendidikan, 14(2), 181-188.

Dewi, D. L. K., \& Muslikah, M. (2021). The Correlation of Coping Stress and Social Support with Academic Stress on Distance Learning. Bisma The Journal of Counseling, 5(2).

Ekayani, P. (2017). PENTINGNYA PENGGUNAAN MEDIA PEMBELAJARAN UNTUK MENINGKATKAN PRESTASI BELAJAR SISWA.

Fadilah, E., Yudhapramesti, P., \& Aristi, N. (2017). Podcast sebagai Alternatif Distribusi Konten Audio. Jurnal Kajian Jurnalisme, 1(1).

Fan, C.-H., Juang, Y.-T., Yang, N.-J., \& Zhang, Y. (2021). An examination of the effectiveness of a school-based behavioral consultation workshop. Consulting Psychology Journal: Practice and Research, 73(1), 88.

Gunarya, A., Tamar, M., \& Ibnu, I. (2010). Bersahabat Dengan Stress. Diakses Dari Http://Repository. Unhas. Ac. Id/Bitstream/Handle/123456789/3, 4(10).

Janna, S. R. (2021). The Academic Stress of Final-Year Students in Covid-19 Pandemic Era. AL-ISHLAH: Jurnal Pendidikan, 13(1), 80-89. 
Jannah, K., \& Baqiyatussolihat, B. (2021). The Influence of Youtube as a Classical Guidance Media on Student Learning Motivation during the Covid-19 Pandemic. Bisma The Journal of Counseling, 5(2).

Joseph, N., Nallapati, A., Machado, M. X., Nair, V., Matele, S., Muthusamy, N., \& Sinha, A. (2021). Assessment of academic stress and its coping mechanisms among medical undergraduate students in a large Midwestern university. Current Psychology, 40(6), 2599-2609.

Laila, D. (2021). Inovasi Perangkat Pembelajaran Menggunakan Aplikasi Podcast. Prosiding Seminar Nasional Pembelajaran Bahasa Dan Sastra Indonesia (SemNas PBSI)-3, 7 12.

Lin, L., Zhang, J., Wang, P., Bai, X., Sun, X., \& Zhang, L. (2020). Perceived control moderates the impact of academic stress on the attention process of working memory in male college students. Stress, 23(3), 256-264.

Mahapatra, A., \& Sharma, P. (2020). Education in times of COVID-19 pandemic: Academic stress and its psychosocial impact on children and adolescents in India. International Journal of Social Psychiatry, 0020764020961801.

Martha kusuma, E., Auliasari, K., \& Orisa, M. (2020). PENGEMBANGAN PODCAST APLIKASI PANDUAN AKADEMIK (APIK) JURUSAN TEKNIK INFORMATIKA ITN MALANG BERBASIS ANDROID. JATI (Jurnal Mahasiswa Teknik Informatika), 4(1), 19-25. https://doi.org/10.36040/jati.v4i1.2384

Mayangsari, D., \& Tiara, D. R. (2019). Podcast Sebagai Media Pembelajaran Di Era Milenial. Jurnal Golden Age, 3(02), 126-135.

Moawad, R. A. (2020). Online learning during the COVID-19 pandemic and academic stress in university students. Revista Românească Pentru Educaţie Multidimensională, 12(1 Sup2), 100-107.

Mosanya, M. (2021). Buffering academic stress during the COVID-19 pandemic related social isolation: Grit and growth mindset as protective factors against the impact of loneliness. International Journal of Applied Positive Psychology, 6(2), 159-174.

Muslim, M. (2020). Manajemen stress pada masa pandemi covid-19. ESENSI: Jurnal Manajemen Bisnis, 23(2), 192-201.

Oktavia, W. K., Fitroh, R., Wulandari, H., \& Feliana, F. (2019). Faktor-faktor yang mempengaruhi stres akademik. 8.

Ponnusamy, S., Iranmanesh, M., Foroughi, B., \& Hyun, S. S. (2020). Drivers and outcomes of Instagram Addiction: Psychological well-being as moderator. Computers in Human Behavior, 107, 106294.

Quintana, D. S., \& Heathers, J. A. (2021). How podcasts can benefit scientific communities. Trends in Cognitive Sciences, 25(1), 3-5.

Rajic, S. (2013). Educational use of podcast. The Fourth International Conference on ELearning, 90-94. 
Ridha, M. A. A. (2021). Model Manajemen Media Podcast RadioMu dalam Spotify. Jurnal Audiens, 2(1), Article 1. https://doi.org/10.18196/jas.v2i1.10210

Saputra, N. M. A., \& Muharammah, N. W. (2020). Elaborasi Bimbingan dan Konseling pada Pendidikan Non Formal Sebagai Wadah Self Development di Tengah Kondisi Pandemi Covid-19. Prosiding Seminar Bimbingan Dan Konseling, 23-26.

Saputra, W. N. E., Supriyanto, A., Rohmadheny, P. S., Astuti, B., Ayriza, Y., \& Adiputra, S. (2021). The Effect of Negative Peace in Mind to Aggressive Behavior of Students in Indonesia. European Journal of Educational Research, 10(1), 485-496.

Saputra, W. N. E., Wahyudi, A., Supriyanto, A., Muyana, S., Rohmadheny, P. S., Ariyanto, R. D., \& Kurniawan, S. J. (2021). Student Perceptions of Online Learning during the COVID-19 Pandemic in Indonesia: A Study of Phenomenology. Student Perceptions of Online Learning during the COVID-19 Pandemic in Indonesia: A Study of Phenomenology, 10(3), 1515-1528.

Sari, P., Bulantika, S. Z., Dewantari, T., \& Rimonda, R. (2020). Effects of stress coping and emotion regulation on student academic stress. KONSELI: Jurnal Bimbingan Dan Konseling (E-Journal), 7(1), 73-80.

SE-Menteri-Pelaksanaan-Pendidikan-24-03-2020.pdf. (2020). Retrieved September 2, 2021, from https://www.expontt.com/wp-content/uploads/2020/03/SE-Menteri-PelaksanaanPendidikan-24-03-2020.pdf

Shehadeh, J., Hamdan-Mansour, A. M., Halasa, S. N., Hani, M. H. B., Nabolsi, M. M., Thultheen, I., \& Nassar, O. S. (2020). Academic stress and self-efficacy as predictors of academic satisfaction among nursing students. The Open Nursing Journal, 14(1).

Sibuea, M. L., \& Safta, A. (2017). Pemetaan Siswa Berprestasi Menggunakan Metode KMeans Clustring. JURTEKSI (Jurnal Teknologi Dan Sistem Informasi), 4(1), 85-92. https://doi.org/10.33330/jurteksi.v4i1.28

Sudarmoyo, S. (2020). Podcast sebagai Alternatif Media Pembelajaran Jarak Jauh. Edudikara: Jurnal Pendidikan Dan Pembelajaran, 5(2), 65-73.

Supriyanto, A., Hartini, S., \& Wahyudi, A. (2019). What is The Character of Student Tolerance in The Indonesian Political Situation? Multicultural Education, 10, 11.

Suriansyah, A. (2011). Landasan pendidikan. COMDES.

Suryani, L. (2017). UPAYA MENINGKATKAN SOPAN SANTUN BERBICARA DENGAN TEMAN SEBAYA MELALUI BIMBINGAN KELOMPOK. E- Jurnal Mitra Pendidikan, 1(1), 112-124.

Yuneti, E. (2017). JURUSAN PENDIDIKAN AGAMA ISLAM FAKULTAS TARBIYAH DAN ILMU KEGURUAN INSTITUT AGAMA ISLAM NEGERI (IAIN) PURWOKERTO 2017. 25. 